\title{
SOME PRINCIPLES OF LEGAL EVOLUTION
}

Every lawyer attempts to be a prophet. Your client does not care what judges have said in the past, nor even what they are saying in the present; he wants to know what they will say in the future, at the time when his case comes up for adjudication. Yet the average lawyer seldom consciously studies the future, and though he may say with the patriot that he knows no method of judging the future save jy the past, yet it is only by keeping his mind fixed upon his desire to prophesy that he can accomplish things worth while.

Just now lawyers are speculating in this rather futile manner about many unsettled matters. They are trying, by the simple but time-honored process of analysing the phrases of judicial opinions, to guess the future policy of the courts with reference to the Bill of Rights in all its ramifications, the control of large corporations, the rights of labor, the reconcilment of divorce legislation, and many other problems. Yel at the same time all authoritative writers admit that these questions are being settled, not by the rule of stare decisis, but by something else, by some other mighty but unspoken principles.

What are these principles? In their application to specific changes some of their results have been pointed out. It has been said, for example, that the idea of property is changing, that the laissez faire idea is exploded, that the Constitution of the United States is now regarded in many courts as obsolescent. But why not look a step further back to those permanent principles whose tendencies are permanent? We shall then, by realizing more clearly the trend of event, be able perhaps to prognosticate with more assurance and greater certainty.

In every general but, it is hoped, helpful way it may be said that legal evolution is brought about by four causes.

1. Changes in the pressure of the law-making forces.

2. A clearer perception of economic needs.

3. The development of greater moral courage.

4. Improvements in legal machinery.

All of these except the first are in line with the general evolution of the race and it may therefore be predicted that an unsettled law will eventually be settled in the direction of higher evolution unless deflected by the first influence. 
This first influence had better be briefy considered now. Many authors have recognized and discussed the fact that all law is the result of a balancing of selfish interests. What those interests are now and how they act is not so well determined. In this article there is no room to go further in to the subject than to say that the strongest, if not the almost inclusive groups are the "master" group (consisting of the mercantile and financial interests and the political bosses) who devote their main efforts to controlling the machinery and scope of government, often by unfair means; the middle group (of skilled and educated citizens) whose strength is felt in measures looking to greater fairness in the law; and the "subject" group (of the unskilled, the impecunious and the ignorant) who are of slight initiative and little moral strength and are often tools in the hands of the master class. The balancing of these groups, the increase of pressure by one or the relaxing of pressure by another, makes and unmakes laws, and these pressures do not change solely in the line of higher development but according to temporary waves of prosperity or financial depression according to other more or less accidental economic conditions. The tracing of these elements in legislation is difficult because the "master" class seldom works by passing a given law. Being normally in the voting minority their business is to prevent a "middle" or "subject" class proposal from coming to a vote, and this they accomplish by advocating and securing in various ways and through different influences judges who are ultra conservative, legislators who are opposed to change, and executive officials who have a sufficient regard for persons and institutions of conventional importance..

The "middle class, on the other hand, produces the bulk of legislation, especially of a reformatory kind. It may therefore be prognosticated that as conditions indicate the increase or decrease of the size and activity of the "middle" group, law reforms will be keener or duller. We have been watching a tremendous era of legal innovation during the last fifteen years. Part of it is undoubtedly due to the increase of the middle class. This increase comes from the very general practice within the same period of educating children through and beyond the high school in studies which tend to make trained workers (typewriting, shorthand, sloyd work, book-keeping, dress-making, cooking, and the mechanical arts). Enormous numbers of girls 
alone, who under a former system were taught merely polite accomplishments, have thus been raised out of the "subject" class and into the "middle" class. Hence the insistence of these trained workers upon the right to vote. There have been millions of merely intelligent women in the centuries of civilization of the past, but mere intelligence coupled with economic uselessness and dependence were not enough to secure legal recognition. Professional training, education, and increased earning power have changed the status and activity of women and will, as these advantages become more general and more productive, inevitably bring about the suffrage privilege in all the states. The "middle" group is also being filled up by an increase in the number of workmen whose trades require a high degree of intelligence. Electrical work, automobile work, intricate machine work, all take the workers out of the group of semi-automatons and make them more critical of their conditions. For this reason labor legislation is bound to increase in volume though checked by the "master" group, working with the balance of the "middle" group to prevent the laborers from pushing through laws which would interfere with the safety and order of the community. In other words labor, in spite of its numbers, inherits the weakness of the subject class from which it sprang, and can never overcome the combination of the strongly intrenched "master" group and the bulk of the stubborn "middle" group.

The "master" group has fought hard to maintain its position in America, and aided by fortunate natural conditions and brilliant individual generals, has succeeded more completely here than in any other civilized country. In consequence they have so retarded the justice-loving "middle" class that although not hampered by a hereditary aristocracy and a large standing army we have fallen behind most of the European nation in such matters as the prevention of political corruption, the efficiency of the courts, the care of the aged poor, the control of the monopolies, the encouragement of the arts, and numerous other works of civilization. The breaking up of this control is now advancing, however. The control was obtained during a period when the "middle" group, used to simple lives, found it easy to satisfy their natural wants, and this condition created an indifference to the encroachments of the "master" types. The fertility and wealth of the country remaining practically the same, and the habits of the middle group type having grown more expensive, 
the latter are beginning to feel the sting of financial stringency. The "high cost of living" became a growing djinn out of the battle of modern life. And the "middle" group is roused to action. It is a newly edited "middle" group with many additions and appendices and it is attacking a "master" group which, while it is one of the most powerful in history, is no match for the aroused young giant. The "subject" group too is smaller, much smaller and harder to dominate. Nor is the mass of it mobilize into the convenient form of a standing army as in Europe.

Unless another wave of great prosperity passes over the country or unless some unforeseen and almost inconceivable influence arrests the practical education of the people, or unless an enormous tide of immigration from countries of low intellectual standards swells the subject class, the "masters" and the "subjects" will continue to dwindle and the middle group to grow. This middle group, alone of the three, is sensitive to evolutionary forces, and the remaining causes of legal evolution may be considered practically in relation to their action upon this section.

The second influence, then, in the order named, is the clearer perception of economic needs. This includes a more scientific idea of justice, of the duty of the citizen, of economic theories. It is responsible for the conception that quasi public corporations are not entitled to the freedom from restraint that private individuals are allowed. It is recognizing the necessity of protecting workmen from the tyranny of unfair employers by the passing of workmen's compensation acts, exploding the old notion that because a workman's contract with his employer was voluntary he could not complain of its harshness. It is working in an especially complex and astute manner in the matter of challenging the rights of the courts to legislate. This process practised and admitted from time immemorial under the thin sham of other processes (distinction, analogies, fictions, etc) is now seen to be immoral, and the judge himself, until recently a fetish, is criticised in respectful but emphatic terms by types of citizens who would formerly have been horrified at such an act. That the Supreme Court itself is beginning to break under the weight of this popular feeling is shown in the opinion of Justice Harlan in U.S. v. the Standard Oil Company, 221 U. S. 1, 75 concurring with the conclusion reached by other members but dissenting from the reasoning. 
*** "The court has now read into the Ast of Congress, words which are not to be found there, and has thereby done that which it adjudged in 1896 and 1898 could not be done without violating the Constitution-namely, by interpretation of a statute changed a public policy declared by the legislative department.

- To overreach the action of Congress merely by judicial construction, that is, by indirection, is a blow at the integrity of our governmental system, and in the end will prove most dangerous to all." Nevertheless, in spite of the aged jurist's protest, the process of judicial legislation in opposition to the obvious intent of statutes and in usurpation of the functions of legislatures will probably go on for a while. But the hand has written the message on the wall.

All this is only by way of illustrating the evolution of law in the direction of clearer perceptions of honesty and justice. The point is not that judge-made law is bad, buc that the people have come to the conclusion that judicial usurpation is bad. Other examples readily present themselves. The new notions that politicians should tell who their financial supporters are, that laborers should not be allowed to cripple industry by unreasonable strikes; that criminals should not escape punishment by inconsequential mistakes of practice or pleading, these and many others are reforms actually in force or becoming law because of the finer reasoning and more sensitive public conscience of the growing and awakened middle group.

The third principle of evolution is the accession of moral courage by the community. In this line come the passing and enforcement of laws against things which in the previous epochs were regarded as "necessary evils," "unavoidable abuses," "incidents of commerce," and other condoning phrases. The distinction between these and the evils treated under the preceding head is that while the conception, for example, that laborers are, in a way, coerced into taking employment is a new one in the law and the legislation thereon cleals with newly discovered wrongs, this third principle deals with abuses which have long been known to exist but which public opinion fails to abate.

This is really a curious and refreshing inquiry. It is interesting indeed to watch the gradual disappearance of the apparently well established convictions that procurers and panders were inseparable from a high degree of civilization; that merchants could not be prevented from adulterating their wares; that bribery by 
indirect means is a natural accompaniment of political machinery; that there was no protection for those foolish enough to believe in schemes promoted through the mails; that there were too many difficulties in the way of putting into effect a genuine income tax. How splendidly have all these principles of the Lotus Eaters been dissipated! Even the time honored "Caveat emptor" has been made to sound strangely archaic.

The fourth line of legal evolution is the introduction of better legal machinery, better means of determining the will of the community and of enforcing it without needlless delay, with as little uncertainty as possible, as cheaply as efficiency demands. The distinction must now be made between the third and fourth principles. It is perhaps fairly obvious. The adulteration of food offered for sale is an acknowledged evil; the form of prohibiting law to deal with it is not difficult to work out; the trouble was that the evil was minimized and condoned. On the other hand the passing of laws by corrupt or defiant legislatures in opposition to the real wishes of their constituents or the long and disheartening delays between suit and trial are defects which cannot be removed without shaking the very foundations of our legal system and consequently call for great skill and daring on the part of reformers. The recall of judges, the referendum, the initiative, the restricting of appeals, the complex plans for clearing the docket, are examples of these reforms. It is here that evolution has its hardest task, for some "reforms," alas, are not reforms at all, except in the literal sense. And it is much easier to destroy the structures of legal procedure than to build them up in a satisfactory manner. The edifice which has become a picturesque but dangerous ruin gives place to one of straight and simple lines; but the tenants enter in with fear and trembling, not knowing where to find the rights which for so many years lay in their accustomed places; not knowing if they will find those rights at all.

Yet to come down to plain language, procedure in this country has come to a sorry pass. Lawyers and judges on all hands admit that, in the words of one of them, referring to the criminal branch, it is "a disgrace to civilization." The reason or reasons are found in the inertia or imitative instinct of the race, in the obtuseness of legislators, and in the sheer laziness and self satisfaction of those whose duty it is to see that the law keeps pace with the rest of civilization. In the course of time, the evolutionary factors already named have pointed out and will point 
out these anachronisms but merely perceiving the right and having courage to enforce it are not enough for this peculiarly intricate defect. It is necessary to work out with all the skill, care, and knowledge available a great many elaborate theories and applications. Of course some anomalies of procedure are now obvious and can be abrogated by brief and simple statutes. Thus the time is not far distant when public opinion will relegate to the legal limbo that survival of the reaction against torture, the rule that a defendant in a criminal trial cannot be interrogated. This particular reform comes under the head of clearer perceptions alone. But the changing of our entire criminal procedure from the controversial system to the inquisitorial system is an entirely different process. So also will be the introduction of a scientific department attached to the courts. So too will be the reform of pleading from a system which is "admirably devised", to use Bentham's phrase, for the purpose of helping dishonest litigants to bolster up their cases, while at the same time they mislead the other side, to a system based upon psychological laws and endeavoring to trap the perjurer from the very outset. This fourth form of evolution is really a different stage in itself, built upon the others. It works by a different technique and with more highly organized faculties. It is the true art of the lawyer, the greatest service he can render his profession and his country. It is naturally beset with more intellectual dangers and pitfalls than the simple course of discovering an evil and affixing a penalty to it. The innovator in this field is bound to make mistakes, to find every obstacle of progress opposed to him, to see many of his schemes abortive, yet it is his duty to continue his quest for the juridical ideal. That is the lawyers real function, a higher one even, it seems to me, than the defense or prosecution of one individual or another. Defense and prosecution are his trade, for which he is hired and paid, and faithfulness to his client is mere common honesty. But the improvement of the law is a poetic ideal, and unselfish goal which lifts the lawyer out of sordidness and into the nobler life.

And like all other aspiration it brings eventually a spiritual reward, for as the lawyer's aim, both practical and ideal is to be a prophet, so in aiding the establishment of justice more of the inner nature of legislation must necessarily be revealed to him and must at last invest him with some part of the prophetic mantle.

Boston, Mass.

William M. Blatt. 